\title{
Documentary Evidence for the Eighteenth and Nineteenth Century Location of the Adaes Indians
}

Darryl Pleaseant

Unknown

Follow this and additional works at: https://scholarworks.sfasu.edu/ita

Part of the American Material Culture Commons, Archaeological Anthropology Commons, Environmental Studies Commons, Other American Studies Commons, Other Arts and Humanities Commons, Other History of Art, Architecture, and Archaeology Commons, and the United States History Commons

Tell us how this article helped you.

This Article is brought to you for free and open access by the Center for Regional Heritage Research at SFA ScholarWorks. It has been accepted for inclusion in Index of Texas Archaeology: Open Access Gray Literature from the Lone Star State by an authorized editor of SFA ScholarWorks. For more information, please contact cdsscholarworks@sfasu.edu. 
Documentary Evidence for the Eighteenth and Nineteenth Century Location of the Adaes Indians

\section{Creative Commons License}

\section{(c) (1) (8)}

This work is licensed under a Creative Commons Attribution-NonCommercial 4.0 International License 


\title{
DOCUMENTARY EVIDENCE FOR THE EIGHTEENTH AND NinETEENTH CENTURY LOCATION OF THE ADAES INDIANS
}

\section{Darryl Pleasant}

\author{
Introduction
}

The location of the habitation sites of the Adaes Indians has not been thoroughly investigated by archaeologists and historians. Most researchers have placed Adaes habitation sites in the general vicinity of Los Adaes simply because the presidio and mission were named after the Adaes Indians [e.g. Hodge (1907:13), Glover (1935), Swanton (1946:196), Webb and Gregory (1986:28), Smith (1995:59), LaVere (1998:79), Avery (1998, 94-95), Los Adaes Exhibit, Texas Beyond History (2006)]. This paper will focus on historical documentation to provide a better understanding of the location of the habitation sites of the Adaes Indians during the $18^{\text {th }}$ and early $19^{\text {th }}$ centuries. The earliest accounts presented are narratives of travels along the Red River in the early 18th century. While they unfortunately have no definitive geographical data such as plat maps or land claims, they still provide relational information which can be interpreted along with the more precise geographical documentation of the latter 18th century. All of the late 18th and early 19th century documents reviewed for this paper are primary sources such as conveyances, successions and land claims.

The evidence presented in this paper will reveal that the "homeland" of the Adaes was in southern Desoto Parish, Louisiana and extreme northern Natchitoches Parish. This area is approximately twenty miles north of Los Adaes, which agrees with the Spanish documents and with John Sibley's (1807) location of the Adaes. Archaeologically, there is an abundant sample of historic sites that date to the 18th and 19th centuries in that region. These appear as pure aboriginal sites or mixtures of aboriginal and European components.

\section{Land Claims}

The land claims mentioned within this article must be described in some detail in order to understand the associated terminology when discussing individual land claims. Throughout the remainder of this article mention of land claims will refer to Old Board, Register and to Rio Hondo claims (Figure 1). These will refer to specific instances of congressional overview of land claimed within former foreign-owned territory in what would become the state of Louisiana.

After the Louisiana territory was purchased by the United States in 1803, and again in 1821 when the Neutral Strip became part of the United States, private property ownership in the newly acquired territory was an unknown factor facing the government of the United States (Haggard 1945). There was great debate over how to deal with the ownership of Public Land and who had authority within the foreign governments to issue land patents. Public Land in this case was identified as land acquired from a foreign government though purchase such as the Louisiana Purchase or through treaties such as the territory acquired by the Adams-Onis treaty within the former Neutral Strip. 


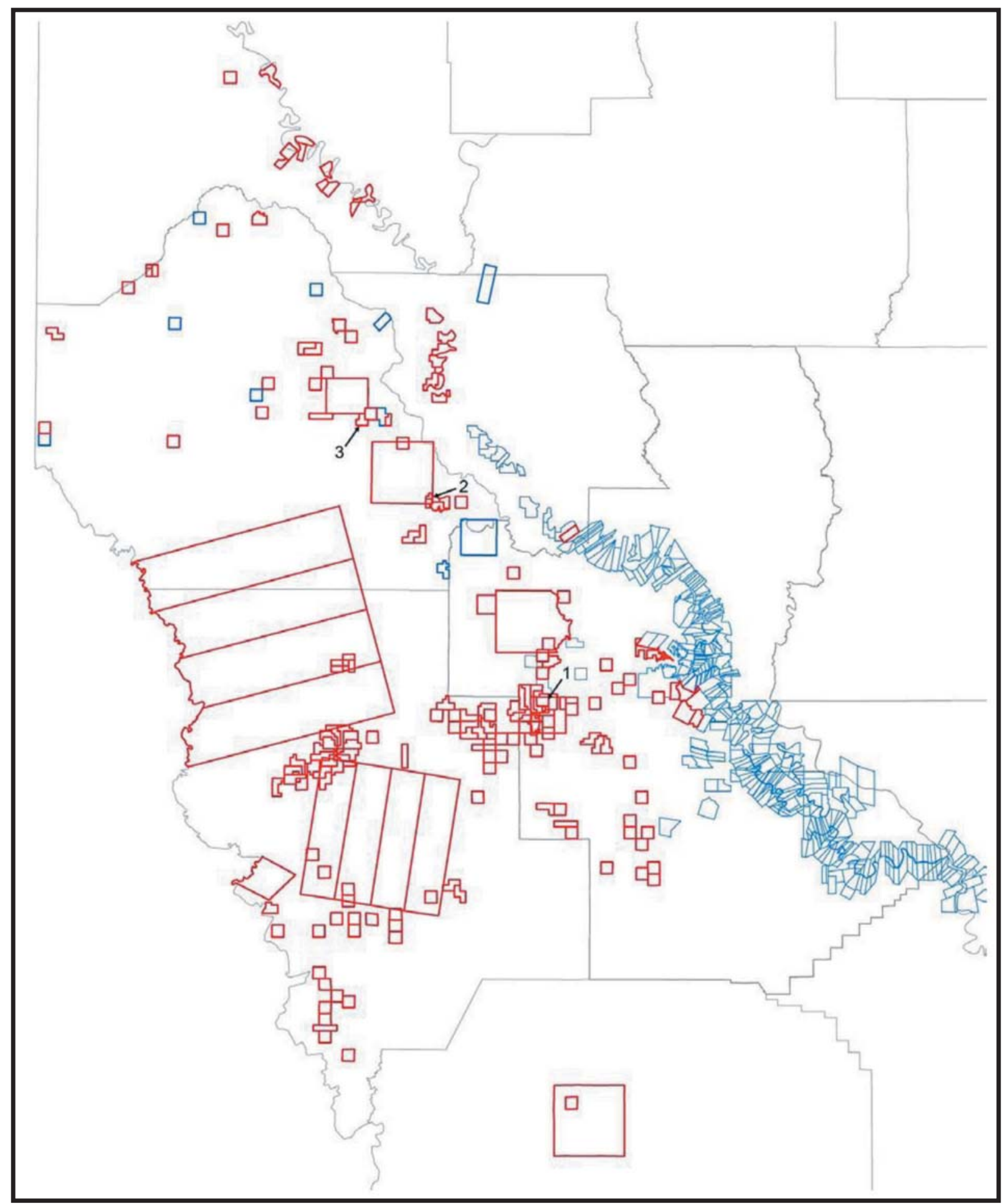

Figure 1 Land claims in northwestern Louisiana. Rio Hondo claims are red and Old Board-Register claims are blue. (1) indicates the Los Adaes presidio. (2) is the Prudhomme and Dolet claims (Tacuachil). (3) is the Valentine, Procello and DeSoto claims (Anadehes). This map represents portions of 9 different volumes of land claims just for the area west of the Red River. 
A series of congressional acts were passed into law starting in 1805 and continuing up to the 1850 s and beyond to deal with the question of land ownership. These dealt primarily with ownership of land during the period that Louisiana was part of Spain and France. Several additional acts were later passed that dealt with the land claims within the Neutral Strip. The documentation of the claims was under the review of the board of commissioners but actual confirmation of all claims was under the authority of congress.

During the first half of the nineteenth century over a half dozen acts of congress were passed that dealt with land claims in the present state of Louisiana. The Acts of 1805 and 1823, and the supplemental acts associated with each, encompass nearly all land claims in the Orleans territory (Louisiana) and the Neutral strip. Land claims in regions such as Natchitoches, Pointe Coupee, and Opelousas and later the Neutral strip were all encompassed in some form by at least one of the acts of congress.

Act of March 2, 1805

The first act relates to the claims in the Louisiana District and the Orleans territory and is "An act for ascertaining and adjusting the titles and claims to land, within the territory of Orleans, and the district of Louisiana" passed on March 2, 1805 (Statutes 1805). The land claims documents generated by this act and the act of March 3, 1807 have come to be known as the "Old Board" claims. A series of supplementary acts were passed on March 10, 1812, February 27, 1813, April 12, 1814, March 3, 1819, May 11, 1820 and February 6, 1835. At various times these are referred to as "Register" or "Register and Receiver" documents.

In 1804, the Louisiana Purchase had already been divided into the Orleans Territory-that eventually became the state of Louisiana-and the Louisiana District which encompassed the remainder of the Louisiana Purchase. In the act of 1805 the Orleans territory was further divided into two districts. Each of these new districts had a register and two commissioners that together comprised a board of commissioners, from here on referred to as the Board or the Register, which oversaw land titles.

The 1805 act required that claimants with complete titles from the Spanish or French as of October 1, 1800 should file those claims in writing with the register of their district. Those with incomplete title were required to be in possession of the land by October 1,1800 and should have been eligible for a complete grant by either the Spanish or the French. Also allowed were those claimants with incomplete title who simply had permission from the Spanish authorities to occupy their lands on December 20,1803. All claims with incomplete title were required to be inhabited and cultivated on the specified dates and the claimant was to be a head of a family or at least twenty-one years of age. Their notices were to be delivered to the register along with descriptions and survey plats of the land claimed. The 1807 supplementary act removed the head of household and the age stipulations.

Along with the actual statements from claimants, witness testimony was taken into evidence for the lands claimed. The question asked of witnesses in the original act included 1) Are you acquainted with the claimant named in the commission, and do you know and can you describe the situation of the land claimed 2) Do you know that the said tract of land has been inhabited and cultivated, and how early and how long continued 3) Do you know the age of the claimant and what is his age (witness) 4) Is the claimant the head of a family and if so how long has he been so (LSLO 1815b:4). The answers to these questions are the information that is seen in some form in all the Old Board and Register land claim documents. 
The act of March 2, 1805 set up the framework for the subsequent land survey of the Orleans territory and the process of land claims and the confirmation of those claims. Unfortunately this was a very flawed approach that as Harry Coles (1979:76) states:

... established a system of dealing with private land claims that was to cause an infinite amount of administrative difficulty and to delay the final settlement of foreign land titles for nearly a century.

Evidence of this can be seen in the fact that as late as 1969 the Bureau of Land Management (BLM) was still issuing land patents for claims nearly a century and a half after they were initially filed.

\section{Act of March 3, 1823}

The second act relates only to those claims in the Neutral Strip and is "An act providing for the examination of the titles to land in that part of the state of Louisiana, situated between the Rio Hondo and the Sabine river" passed on March 3, 1823. A supplementary act was passed on May 26, 1824 and a third act that revived the first two acts for two years was passed on August 3, 1854.

The Act of March 3, 1823 set up what has come to be known as the Rio Hondo claims. A vast majority of the claims in the Bayou Pierre settlement are Rio Hondo claims filed under the first two acts in 1823 and 1824. Only a few claims, all within the Bayou Pierre settlements were filed under the 1854 Rio Hondo act. Within the Neutral Strip several claims had already been filed under the Old Board but were also filed much later under the Rio Hondo acts.

The Rio Hondo act was to establish title to lands within the old Neutral strip as of the date of the signing of the Adams-Onis treaty on February 22, 1819. The treaty finally set the boundary of the United States at the Sabine River and as a result all the territory within the Neutral Strip became part of the United States. The Rio Hondo claims were separated into four classes. The first class was based on complete title to land and the second class was based on incomplete titles but with provisions that they would meet guidelines for complete title to the land according to the laws of the Spanish government. The claims of the third class had no titles but instead were based on occupation, habitation and cultivation of a claim prior to and on February 22, 1819. Claimant and witness statements had to show that the claimant not only owned the land in question but also had to be occupying it and actually cultivating the land. Land owners did not have to personally do this as they could have others working the land for them as tenants. It is fairly obvious that these classes mimic the guidelines of the act of March 2, 1805.

The fourth class was those claims that were not confirmed. Some claims were denied due to their being multiple filings by land owners, in essence only one claim per person was allowed [see Rio Hondo claim \#53, 174, 191, 206 (ASP 1859:100, 122, 126, 130)]. Many claims were not confirmed due to the land being unoccupied for a length of time after initial occupation by either an owner or a tenant. Since there was no title to these lands this broke the chain of occupation and cultivation and the land once again became part of the public domain [see Rio Hondo claims \#121 and \#123 (ASP 1859:113)]. An exception to this rule was made for some of those who were expelled from their lands by force. The board ruled under Rio Hondo claim \#217 that when the United States expelled Andrew Franks from his lands in 1812 and burned his house he did not voluntarily abandon his claim but was coerced to leave by "superior authority" (ASP 1859:132) as such his claim was confirmed. 
The Neutral Strip which is so essential to the whole idea of Rio Hondo claims has often been mentioned as being between the Sabine River and Young's Bayou near Hagewood, Louisiana. Evidence from the land claim documentation reveals the borders of the strip to be slightly different than usually reported. The Neutral Strip ran from the Gulf of Mexico along the Calcasieu River to Kisatchie Bayou and up Old River into Sibley Lake and then northward along Bayou Hondo toward Bayou Pierre. This is unquestionably an accurate boundary description as there are several land owners within the city limits or just outside of Natchitoches, Louisiana who claimed land under the Rio Hondo act. Also in the Kisatchie Creek area the claims on the west side of the creek are Rio Hondo claims while those on the east side are not.

The congressional acts and the resulting documentation account for nearly every single land claim within western Louisiana. The Old Board and Register acts also involve claims in other regions of Louisiana as well but these were not relevant to our subject. The Rio Hondo acts only involve the claims within the Neutral Strip. [For a very detailed account of the land claim process see Coles (1979)].

The Acts of Congress and the resulting land claim documents were all brought about due to the acquisition of foreign land by purchase and treaty. Much of this new Public Land was already occupied by current or former French and Spanish citizens that essentially made it Private Land. All of the land settled or a bulk of it was granted by either of those foreign governments. Congress sought to deal with these lands by passing the series of acts which obviously did not result in an adequate method of confirming claims.

All of the congressional acts and the resulting documentation of land claims in the western district of Louisiana are readily available at the Library of Congress website (see references). Within this article the claim numbers from all claim reports are labeled by a pound sign. Numbers within parentheses are the actual numerical number or catalog number in that individual report and not an actual claim number.

It must be noted that oftentimes information within claim documents is different in the official published Library of Congress documents as compared to the hand written version of the same document on file at the Louisiana State Land Office. In some cases information is omitted in the official published documents. As a result both instances are used at various times as source material accordingly.

Also when reviewing the Old Board or Rio Hondo claims care must be taken to make sense of the claim statements. The entirety of the claim document must be read to realize the complete picture of succession or conveyance of a claim. Many times the person applying for the land is a very recent owner who purchased the land after an act of congress was passed. This is especially true of the Rio Hondo claims. Some claimants had only recently purchased lands before filing their claims. So to gain a clear picture of settlement the entire history of individual claims must be analyzed.

\section{Geography}

The two major geographic regions important in the location of habitation sites of the Adaes Indians include the region around Los Adaes near Robeline, Louisiana, and the Bayou Pierre region south of Shreveport, Louisiana. A short description of each region will hopefully make the basic theme of this paper clearer to the reader. 


\section{Adaes Region}

The term "Adaes" has been used for many different objects, places and peoples. It is clear that when the term Adaes is used there are geographical, cultural and temporal differences involved, which in many cases are completely unrelated. We can narrow the meanings down to what are important within the scope of this narrative and how it is used within the research and the documentation presented within this article. There are four specific instances of the use of Adaes that must be made clear.

The first is that during the time that the Los Adaes presidio was in full operation and for many decades afterwards the geographical region around the presidio was known as the Adaes. Many spellings of Adaes are found in the documents from the eighteenth and nineteenth centuries-examples include Adais, Adaize, Adayes, Adayas and Adyies. This geographical term as used within the historical documents is in my opinion based more on the presence of the presidio than any continual recognition of the presence of the Adaes Indians. Once the presidio and missions were named after the Adaes Indians the region came to be known as Adaes due to the presidio especially since it was the capital of the province Texas for over 50 years. Any phrase such as "going to the Adaes" meant going to the region of Los Adaes. At no point should the terms Los Adaes and the Adaes (Region) be exclusive. Based on documentation the general region appropriately called Adaes would be the Bayou DuPont drainage basin from the headwaters of Spanish Lake over to the Three Prairies and the uplands between.

Secondly the Village of Adaes is not associated with Los Adaes or the Adaes Indians in any manner other than geography (Pleasant and Pleasant 1990). The presidio had been abandoned for approximately 40 years when the Spanish Village of Adaes was founded in 1813. Any mention of the village is always either stated as Village of Adaes or Spanish Village of Adaes. A comment in a National Park Service brochure (NPS 2011:162163) referred to the village as "Los Adaes Village"; this is not an accurate description of the village as it implies association with Los Adaes. The refugee population that would inhabit the Village of Adaes was familiar with the region and that is the reason they immigrated here rather than elsewhere. The refugee populations that founded the village were referred to as Spanish (ASP 1859:110).

Third are the Adaes Indians. In typical Spanish style the mission and presidio were named for the Indians and it is always presumed they were inhabitants of the Los Adaes area. Evidence to the contrary is found in the land claims from the Spanish and American periods. As time progressed they seemed to have played a smaller role in the area. As such it is not surprising that in all the late eighteenth and nineteenth century land claim documents reviewed concerning the Adaes region from approximately 1775 to 1900 there is no mention of the Adaes Indians. With very few references to the Indians-especially for the post-1803 time period-two things are possible. First they may not have been present in the Los Adaes region and secondly they did not play a substantial role in the events of the region in the years after the presidio was abandoned. [One notable exception is found in John Sibley's Report from Natchitoches in 1807 where he relates that the great Caddo chief had arrived in Natchitoches, and that around 300 Indians of various Nations would be arriving the following day; among those Nations mentioned were the "Adaize" (Sibley 1922:49). The "Adaize" were also among those who were considered to be potential recipients of gifts of provisions and cooking utensils [Sibley 1922:50.]

We do have an adequate collection of land claims in the Bayou Pierre region that are associated with the Adaes Indians. More importantly we also have evidence of historic archaeological sites in the same region that signify habitation by historic Native Americans, most likely the Adaes Indians. But not a single historic

archaeological site recorded within the Los Adaes region and outside the presidio boundaries can be attributed to any historic Native American occupation. 
Lastly, there are multiple drainages named Adaes. This includes the Sabine River which at times was called Rio Los Adaes, the small bayou near the Los Adaes presidio which was called Bayou Adaes and there is the "arroyo aday" or Bayou Adaes within the Bayou Pierre region. As stated earlier there is evidence that the term Adaes was a geographical reference and this is directly responsible for the drainage names near Los Adaes and for the Sabine River. It appears that each drainage name was a direct result of the association with Los Adaes and not to any Native Americans as there is never any archaeological or documented evidence that the Adaes were in any of these other areas. On the other hand there is direct evidence that the Bayou Adaes in the Bayou Pierre region had Adaes Indian habitation sites situated along its course.

\section{Bayou Pierre Region}

The Bayou Pierre region as a whole was the center point for much of the important history of this part of Louisiana. It had a long history of French occupation in the form of traders. It is likely that many of these traders simply stayed in place through the changes in government. Also many of the French within this study are descendants of those early traders.

The Bayou Pierre boundaries were not known except for a general placement somewhere along modern Bayou Pierre. Present day Carmel, Louisiana was often noted as the general region of Bayou Pierre. Evidence from the land claims presents a clearer picture of the boundaries, due to who was considered as living within the settlement and who was considered as outside of the settlement (ASP 1859). The Bayou Pierre settlement was not simply a small community of settlers, it was a large area of dispersed settlements in which several clusters appear in various areas. Overall the Bayou Pierre settlement covered an area around 35 miles north-south and 15-20 miles east-west. This is an area approximately 700 miles square, so this is hardly a condensed settlement.

The southern boundary of Bayou Pierre appears to be Halls Brake and its tributary Rocks Creek just north of Allen, La. Several land claims in this area are listed as being in the Bayou Pierre settlement. The Wallace Lake area just south of Shreveport, La. is the most northerly area of Bayou Pierre; it is around the lake and its tributary Keatchie Bayou that the Bayou Pierre land claims end. There are land claims farther north within the Shreveport, Louisiana city limits but these are not mentioned as being within Bayou Pierre. Most settlements are located along the upland prairies adjacent to the Red River valley and overlooking various Raft Lakes.

\section{Traveler's Accounts}

The first geographical evidence for the location of Adaes Indian habitation sites is from the early and middle $18^{\text {th }}$ century, and represents the period before 1780 , which is an arbitrary date for the appearance of the documented land claims by French settlers from Natchitoches. The difference between the claims after 1780 is that many were still occupied well into the American period when survey plat maps were being produced. It is probable that earlier claims could be located by following the chain of ownership into the American period, especially for the Bayou Pierre Lake region where known French traders were present very early, but that is beyond the scope of this paper. It is also obvious that many claimants that we have information for are not the initial settlers of their claims. So there is a period when some early claims were occupied, but left no available document trail and these probably pre-date the 1780 s. 
These following are accounts of various travelers which have little or no direct geographical information other than general descriptions of distances and directions that have to be inferred by the reader. Based on these descriptions and by the addition of later sources using the same travel routes, the locations mentioned can be determined. These can be followed somewhat accurately and locations can be attributed to a particular region if not an exact location. These documents are important due to their early nature as they show that even during the early eighteenth century the Adaes Indians were already well established in the Bayou Pierre region.

\section{Bernard de LaHarpe}

The first notable traveler that mentions the Adaes was Bernard de LaHarpe who travelled from New Orleans to Natchitoches in 1719, after receiving the right from the French government to establish a trading post among the Caddo Indians along the Red River in Northeast Texas (Wedel 1978). He headed northward from Natchitoches and crossed a series of lakes, most likely Spanish Lake and other raft lakes paralleling Red River. After he left Natchitoches and traveled 3 days he finally encountered the Adayes for the first time. He states the following:

We camped on the high ground, which is on the left going up, which is the country of the Adayes... At three o'clock we entered the big river [Bayou Pierre] upon which we made a league to the north-northwest; we camped then near an Adaye establishment. At the right there were two or three wretched huts scattered about [Smith, 1958:247]

By the time he reached the first Adaye settlement he had travelled almost twelve leagues distance, and with the French league equaling 2.76 miles (Wedel 1978:2; Ekberg 1998:178), he had traveled over 33 miles in a northnorthwest direction. If we understand that LaHarpe traveled around the Grand Ecore bluffs from Natchitoches and then headed northwest on the lakes and bayous along the western valley, this distance puts him in the general region of Evelyn, Louisiana.

LaHarpe obviously was following the western valley wall northwest which carried him into Spanish Lake and onto the Bayou Pierre area. LaHarpe states that his Indian guides were intentionally following the high bank on the left or the uplands to the west so they could hunt and find suitable camping areas since it was high water in the Red River (Smith 1958:248).

On his return trip from the Caddo villages in 1720 LaHarpe took ill and was stranded for a period of time before receiving aid from the Natchitoches and Adaes Indians. He was at an Adaye village during most of his illness and was soon nursed back to health. After he left the Adaye village he headed back to Natchitoches. He states:

They embarked me in a pirogue a little larger than the preceding one. We crossed several lakes, and after having made ten leagues, we arrived at the portage of Natchitoches, two leagues from this post [Smith 1958:539]

LaHarpe, at the time of his illness, was around 16 leagues north of Natchitoches. The Adaye village mentioned was 12 leagues north or approximately 33 miles north of Natchitoches and this places the village in the same general region of Evelyn, Louisiana. This area is the exact vicinity where later French settlers would claim lands within Adaes villages. 
This account along with the accounts of the Aguayo expedition (Buckley 1911:51) having to go and find the Adaes Indians show that even within the early eighteenth century the Adaes were not living in the region of Los Adaes. It seems obvious that they were settled in the same region for most of the eighteenth century.

Fray Miguel Santa María Y Silva

The next account is by a priest in 1770 (Bolton 1914:69). Fray Miguel Santa María Y Silva travelled with the commandant of Natchitoches, Athanase De Mézières, from Los Adaes to the Kadohadocho. In a letter to the Viceroy about his travels Fray Silva does give some generalized geographic evidence. The letter states:

First I set out on the third or fourth of October of the year 1770 from the presidio of Los Adaes with the commandant of the post of San Juan Batista de Natchitoches Don Atanasio de Mecieres ... We arrived the following day at the rancheria of the Adays nation ... at this next village or nation [Yatasi], most excellent Sir, we arrived, as I remember, on the third day. [Bolton 1914:69, $71]$

This account shows that the "rancheria of the Adays nation" was at least one day travel from Los Adaes. It also shows that the party was heading north because after they left the Adays villages they arrived at the Yatasi village and then continued on to the Kadohadacho. It is generally known and the land claim documentation give supporting evidence that the Yatasi villages were around the Bayou Pierre Lake region in southern Desoto Parish.

\section{François Grappe}

An account by François Grappe (LaVere 1998) several years later in 1783 describes a similar route from the Los Adaes region to Bayou Pierre, though the Adaes Indians are not specifically mentioned. In this account François Grappe describes his travels to the Kichai Indians as part of an expedition with the commandant of Nacogdoches Gil Ybarbo. At the Adayes (region or post) he meets Ybarbo and travels the next day northward along presumably the same road travelled by Athanase De Mézières and Fray Miguel Santa María Y Silva in 1774.

The group leaves Adayes early in the morning and after several hours travel they stop at a ranch of $\mathrm{M}$. Labery (LaVere 1998:72). This ranch is probably in the region of Allen, Louisiana. Jean Baptiste LaBerry had married Jeanne Guedon in 1760 who was the widow of Charles Totin. According to various documents the Totins had resided in the Allen, Louisiana region from the latter part of the $18^{\text {th }}$ century and up to at least 1835 (see the Lac Macdon discussion). It is possible that the Totins and LaBerrys had already settled in the general region of Allen, Louisiana by 1774. Also in this area situated along the actual road from Los Adaes is the ranch of François Morvan along Rocks Bayou. His ranch borders the western end of the lands claimed by the Totins. So this party of travelers at this point must be situated somewhere between the Morvan claim and the Totin/ Laberry lands.

After the party left M. Laberys ranch they stopped for the night at the ranch of Sgnr. Dolet, obviously this is Pierre Dolet who had a vacherie just north of Evelyn, Louisiana. This is probably the land that would be granted to Pierre Dolet in the 1790s and called "San Pedro de los Adaes"; it is apparent that Pierre Dolet was already living in Bayou Pierre by the 1780s. The location of this grant is indisputable based on plat maps and documentation (Figure 3). It is noted that the Grappe party travelled six leagues from the last ranch (LaVere 1998:72). This would place Labery's ranch about 16-17 miles south of Dolet's ranch which definitely places it in the Allen, Louisiana area. 
As previously noted the Adaes Indians are not mentioned in François Grappe's diary but the general description of the travels showed that Grappe's party followed the same path that Athanase De Mézières travelled a few years earlier. LaHarpe was probably in the same general region decades earlier as he made his way from Natchitoches across the lakes, but took a more northerly route from Natchitoches toward the region north of Spanish Lake. Most likely he at times traveled the same road, but accessed it at a point farther north than where the later travelers began their journeys. In the early $19^{\text {th }}$ century the road from Los Adaes that ran through the Bayou Pierre settlements and northward was known on various plat maps as the "Road from Natchitoches to Bayou Pierre and Pecan Point". It is probable that this was the same road travelled by these early explorers.

These accounts were general travel accounts with no hard evidence for the location of Adaes habitation sites, but taking into account the direction and distances travelled we can assume the habitation sites were in southern DeSoto Parish, Louisiana. Obviously more primary documentary evidence exists on the Adaes, (see Avery 1995-1998 for a list of documents), although Avery (1997:80) does note, "specific mention of the Adaes is otherwise scanty in the documents dating from 1721 to 1773 ".

\section{Primary Documentation}

The evidence from this point forward is from primary sources. The documents are a combination of archives and conveyances as well as government documents. This includes hard geographical evidence such as Plat maps with associated claim numbers. These maps correlate directly with the Library of Congress documents and the various historic conveyance documents in which many native land purchases are described. Between the plat maps and their correlation with the historic documents we have a very clear picture of the Adaes habitation sites.

The land claims within the Adaes Indian settlements can best be described by discussing each set of claims independently. The goal is to narrow the location of Adaes settlements to specific regions as it seems virtually impossible to specify individual habitation sites without maps of those habitation sites. We also will narrow which modern drainages or lakes were called Bayou of the Adaes, Bayou Macdon and Lac Macdon. These names are found in various documents of the region and determining which modern water body correlates with each historic water body is important in the context of this research.

\section{Prudhommes and Rambins}

The earliest document examined for this study regarding Adaes land claims is a sale from the tribe in 1789 to Athanase Poisot. The document mentions the "Nation Adayes" and more specifically their chief Ouincy, along with his brother Quiouant who seems to have actually been the one who sold the land to Athanase Poissot. The land was named "Tacuachil" and was situated in "bayou au pierre" approximately 15 leagues from the post of Natchitoches (Colonial Archives 1789). Athanase Poissot and his family are often noted in later documents as living among the Yatasi Indians north of Bayou Pierre Lake (ASP 1834:210; LSLO 1835:41-43). There was no indication of any land claims by him south of that area, and no maps were located which showed the area mentioned in the land sale, however, documents from 21 years later present solid evidence for the location of Tacuachil.

In 1810 a list of ranches within the jurisdiction of Nacogdoches was prepared by Spanish authorities which mentions a ranch named "Tacuachilla". María Rambere (Rambin) who was the widow of François Prudhomme (Bexar Archives 1805, 1809) is listed as owning the ranch which is called "Bayou Pierre" and 
"Tacuachilla" (Bexar Archives 1810). The location is simply listed as being 40 leagues from Nacogdoches, Texas however we can determine that François Prudhommes and María Rambin's land claims were located in T11N R11W specifically in sections 11 and 12 as shown in Figure 2.

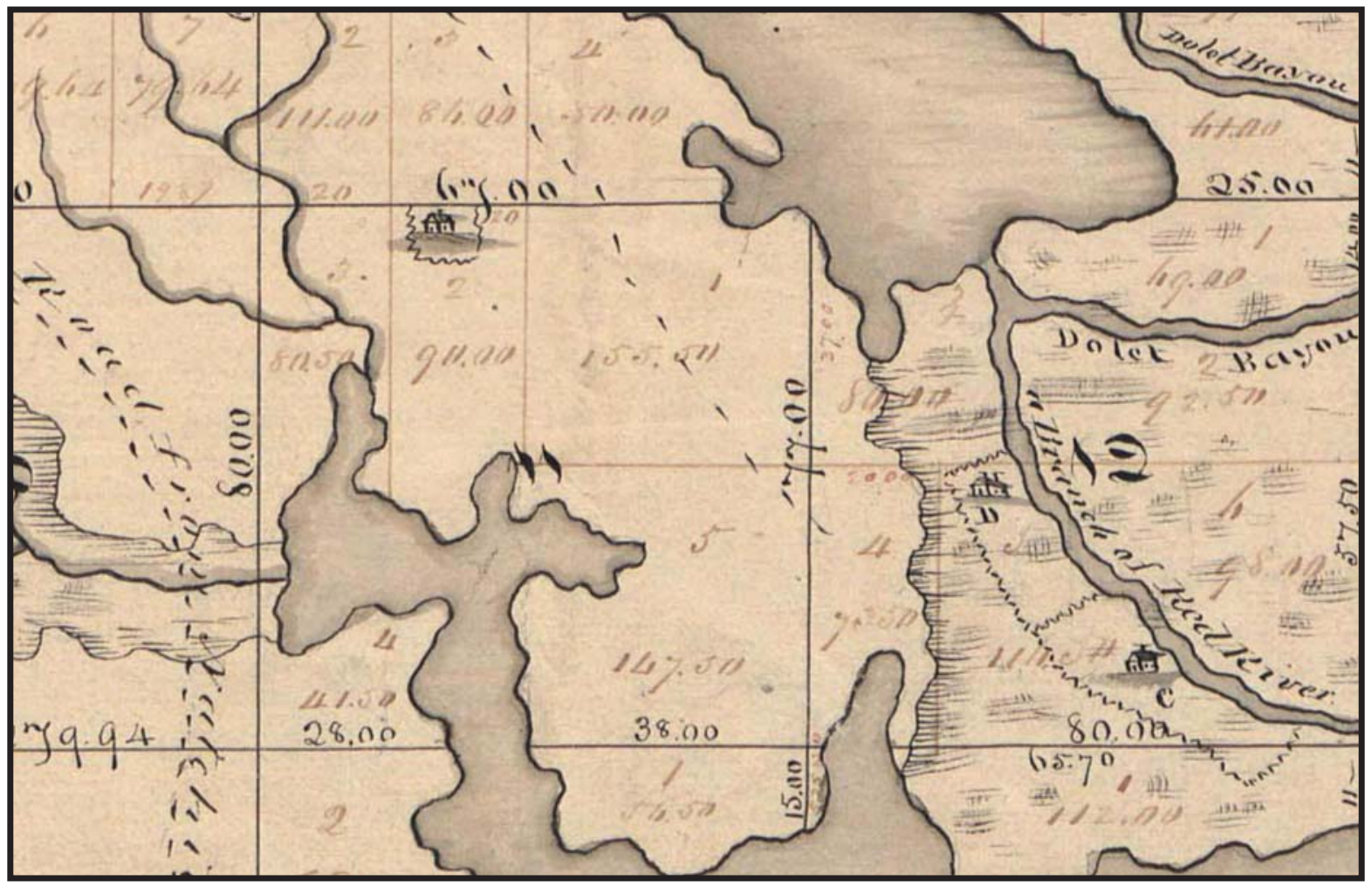

Figure. 2 Land claims of Andre Rambin (C) and François Prudhomme (D) along Dolet Bayou in Desoto Parish, Louisiana. The structure in the upper left is also on Andre Rambin's claim. Louisiana State Land Office Plat Map of Township 11 North Range 11 West.

The fact the Bexar Archives (1810) document also refer to the ranch as "Bayou Pierre" confirms that they are indicating that the "Tacuachilla" ranch owned by María Rambere (Rambin) is located within the Bayou Pierre settlements. Along with the plat maps this give a definitive location of Tacuachilla on Dolet Bayou. The association of María Rambere's "Tacuachilla" claim reveals definitive evidence for the actual location of Athanase Poissot's “Tacuachil” claim.

In a 1797 list of ranches within the jurisdiction of Nacogdoches François Prudhomme is listed as living in the "Pueblo de los Yndios Adaes" (Bexar Archives 1797) This, along with the later document from 1810 stating that his widow is living at "Tacuachilla", places the Prudhommes within the heart of the Adaes settlements. While there are no plats of the actual locations of "Tacuachilla" or the "Pueblo" we do have consistent evidence for the Prudhomme lands along Dolet Bayou.

François Prudhomme died in 1807 so it is obvious the claimant shown in Figure 2 is his son, also named François Prudhomme. The younger François Prudhomme filed two land claims some time before 1816 which were claim \#582 (Cat. 727) for one league square of land and claim \#585 (Cat. 729) for 640 acres while Mary (María?) Prudhomme filed claim \#580 (Cat. 725) for one league square of land (ASP 1834:196). It is possible that the three claims were for the same general tract of land. This type of multiple filing is not unknown within the land claim documents. All three claims were noted as being within the Bayou Pierre settlement. 
Unfortunately, there were no maps located that showed any of the claims mentioned above. We do however have evidence of the location due to a much later geographical description of the lands claimed. The younger François Prudhomme and other heirs of the elder François Prudhomme filed for the square league of land in November 1835. In claim \#177 (US Serial 1842:74) Prudhomme states the claim was two miles north of Wallace Bayou which places it within the same exact location as seen on the plat map in Figure 2. It is stated that the Vacherie had been continually occupied since at least 1793. Further evidence is presented by John Sibley in his Rio Hondo claim \# 118. He states that his land claim which was the old Jacob Wallace grant is on Bayou Wallace and is bound on the north by the heirs of François Prudhomme (ASP 1859:112). The Prudhomme land to the north is obviously the same land that was claimed in 1835 .

The younger François Prudhomme filed Rio Hondo claim \#80 (Figure 2) in the 1820s which was situated along the Bayou of the Prairie Winsy (Winsey) which is possibly modern Dolet Bayou in southern Desoto Parish (ASP 1859:104). This claim is in T11N R11W in sections 11 and 12. The bayou mentioned is not the modern Bayou Winsey which is a small tributary of the Red River in Red River Parish unless the entire floodplain from Dolet Bayou to Red River was considered Prairie Winsy. It is likely this 640 acre Rio Hondo claim was for the same lands claimed previously in the Register documents for a league. Within the land claim documents there are many accounts of league size grants being confirmed for only 640 acres.

In 1801 the younger François Prudhomme purchased a tract of land from an Indian named Octone that is located along "arrollo de los Aday" (Melrose Collection Folder 579). This document is presumed to refer to the land he had already settled with his family along Dolet Bayou as the document stated he lived with his father. It is presumed again that this is all part of the larger grant of the elder François Prudhomme.

Evidence of the location is found in the fact that in 1802 François Prudhommes brother-in-law Andre Rambin who along with his young son François Rambin also purchased land from the same Indian on "arrollo aday... on the two sides adjacent to François Prudhomme" (Melrose Collection Folder 579). Rambin's Rio Hondo claim \#193 (ASP 1859:127) is shown on plat maps of T11N R11W as adjacent to François Prudhomme's in sections 11 and 12 and Rambin's claims surrounds Prudhomme's claim. So these two land purchases by Prudhomme and Rambin are the tracts of land they would later claim under Rio Hondo claim \# 80 and claim \#193 respectively. François Rambin would file his own Rio Hondo claim \#192 in the 1820s, but this would be over twenty years after this purchase.

We can ascertain from the location of François Prudhomme's land claims that they were situated along Dolet Bayou and that María Rambin's ranch called "Tacuachilla" was literally the same as the league square of land they claimed in various filings with the land boards. As such we have adequate information regarding the location of Athanase Poissot's 1789 purchase of "Tacuachil" from the Adayes Indians and can place the claim as along modern Dolet Bayou near Evelyn, Louisiana. We have overwhelming evidence that François Prudhomme and María Rambere (Rambin) were living within the Adaes settlements and were there in the 1790's and probably much earlier. Also, Andre Rambin's claim purchased from an Indian is situated in the same exact region as Prudhomme's claim. Both claims are along Dolet Bayou which can only suggest that the bayou must be the one known as "arrollo de los Aday" (Bayou of the Adaes) mentioned in several documents concerning the Adaes Indians and the surrounding region. 


\section{Pierre Dolet}

Pierre Dolet was one of the more notable residents of the Bayou Pierre settlement and his Spanish land grant (Figure 3) and subsequent land claims play a very important role in the history of the region, not because of specific mention of the Adaes Indians but because of the overwhelming evidence concerning the locations of the Bayou of the Adaes and the location of neighboring claimants such as Joseph Valentine and François Serpentine. Pierre Dolet's claim is still marked on modern USGS topographic maps and there is substantial available information regarding the claim including plat maps, land claim documents, court cases and congressional documents. The document trail leaves no doubt as to the exact location of this claim. As such, all the documents that mention the Adaes Indian villages and have no details regarding location, but reference Dolet's claim can be relegated to a general area within or near his land grant.

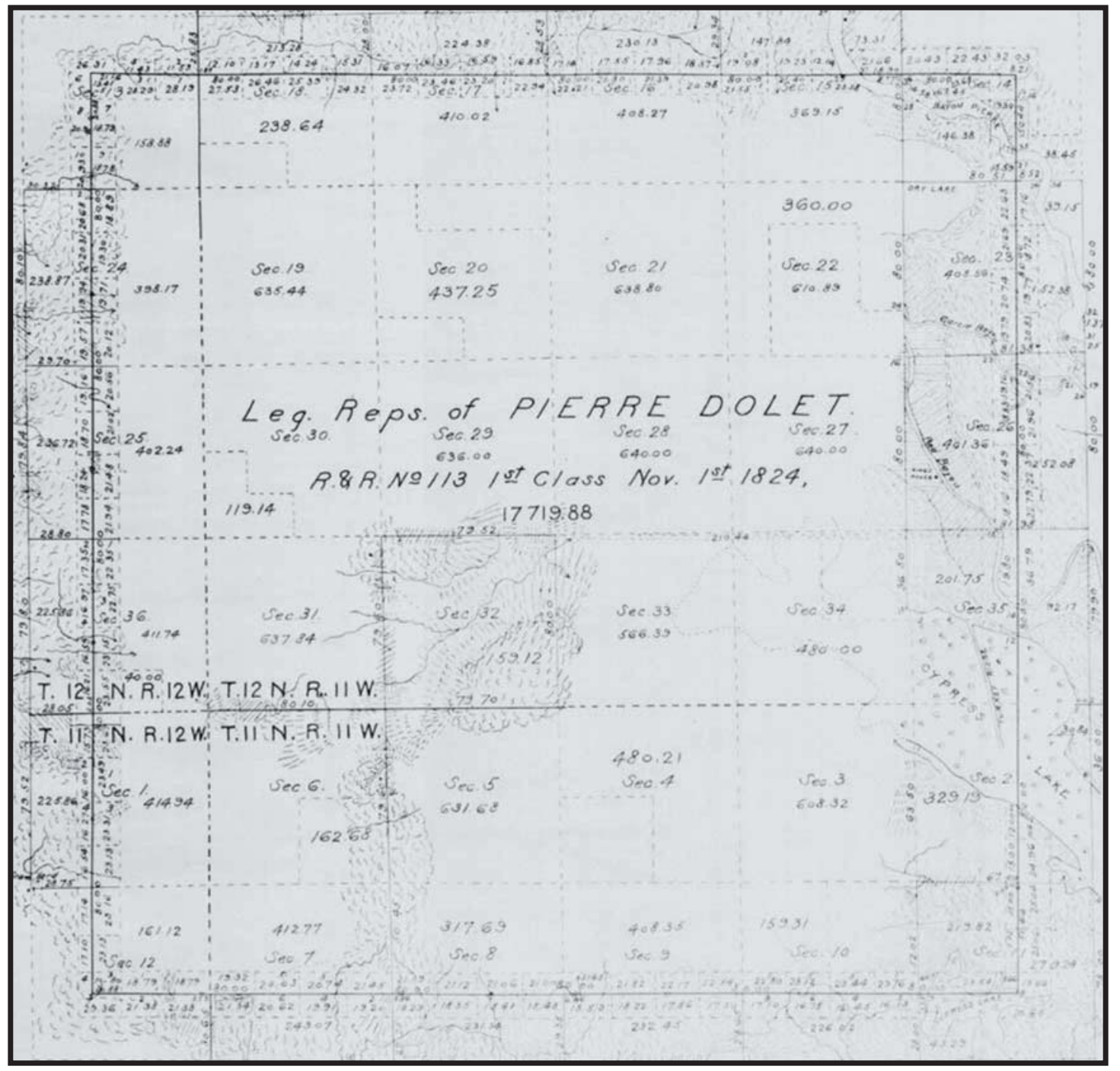

Figure 3 Plat map of Pierre Dolet's Spanish land grant in southern Desoto Parish. This is the grant named San Pedro De Los Adaes by Spanish authorities and filed as Rio Hondo claim \#113. 
Pierre Dolet was already settled in the Bayou Pierre area as early as 1783 as his ranch is mentioned by François Grappe on his travels to the Kichai Indians (LaVere 1998). It can only be presumed that in 1783 he was situated in the region near where he would later obtain the Spanish land grant. It would be 1795 when he formally petitioned for title to this claim, and 1796 when he received it as a Spanish land grant from the Lieutenant Governor of Nacogdoches.

Pierre Dolet filed Register claim \#583 (Cat. 1102) in 1816 for the land on Bayou of the Adaise (ASP 1834:205) but with minimal information contained in the claim. He died in 1822 but the heirs filed land claims afterwards for the Spanish land grant. The Legal Representatives of Pierre Dolet filed Rio Hondo claim \#113 for the two square leagues of land along the Bayou of the Adaise. The Adaes Indians are not specifically mentioned within Pierre Dolet's land claim, but the association with Bayou Adaise and the name given to the grant, all indicate a probable connection to the presence of the Adaes Indians in the region. The main body of the grant is as follows:

situated on the Bayou Adaise, in the settlement of Bayou Pierre, containing one square league around the compass, taking for center the house in which they live, so that the whole tract may form a square of two leagues on each front. that he has made a settlement on one of the margins of the bayou of the Adaise. Whereas Pierre Dolet has made a settlement on the margin of the Bayou Adaise. to the place called bayou of the Adaise where the petitioner claims, and has built his house. being at the designated place on the bayou of the Adaise. he went as he pleased on the said land on the Bayou of the Adaise. I have designated the aforesaid tract of land by the name of San Pedro de los Adaise, so that it may forever go by that name. [ASP 1859:RH113]

The claim covers two square leagues centered on the house as shown in figure 2 and can be pinpointed due to an archive of numerous maps and documents. In fact the claim boundary is still highlighted on modern USGS topographic maps. The Dolet grant spawned several court cases in the mid to late nineteenth century and several additional acts of congress for the relief of the Pierre Dolet heirs.

Rose Dupré, the widow of Pierre Dolet filed Register claim \# 175 (US Serial 1842:73-74) after 1835. The act of congress passed on February 6, 1835 was one of the last relevant acts for the western district of Louisiana. It would include many claims that did not get filed as part of the earlier acts of congress. Rose Dupré's claim was basically a condensed version of Rio Hondo claim \#113 (ASP 1859:111-112) from the 1820s but it did include witness testimony that shed light on some aspects of the Dolet claim.

The 1835 claim document presented testimony by Bertrand Plaisance from 1815 before the land claims board (US Serial 1842:74). Plaisance stated that Pierre Dolet was already settled on the land at least 35 years prior to 1815 which would be around 1780. This is in agreement with the general pattern of settlement of Bayou Pierre, where by the 1780s many French inhabitants from Natchitoches were staking claims. These include Paul Bouett Lafitte in 1784, Marcel Desoto in 1783 and Pierre Dolet in 1780. It is obvious that some were there much earlier especially in the region where the Yatasi Indians lived around Bayou Pierre Lake. Baptiste Grappe testified in 1805 that French traders such as a Mr. Verge (Etienne Verger) and a Mr. de Coto (Bermuda DeSoto) were living at Yattassee Point by at least 1770 and had been there many years before (Annals of Congress 1852:1211-1212).

The general site of Pierre Dolet's house has been archeologically located and designated 16DS274 (Louisiana State Site Files). This claim has been mistakenly considered a probable Yatasi site for many years. 
This is an obvious error as we have ample proof that this site was occupied by at least the 1780s by Pierre Dolet. As will be discussed later, this is not the only known site that was mistaken for an Indian occupation. The detailed location of Pierre Dolet's claim is important due to the fact we now have a starting point for other claims that mention the Adaes Indians, but could not be accurately located. The claims of Joseph Valentine and others mention the Adaes Indians in various conveyances, but the claims are not plotted on plat maps and can only be located by reference to Pierre Dolet's claim.

\section{Joseph and Andre Valentine}

Joseph Valentine and his father Jean Andre Valentine are integral figures in the search for the villages of both the Adaes and the Yatasi. Jean Andre Valentine and Pierre Dolet were half-brothers, which could explain why many of the Valentine claims are situated near or within Pierre Dolet's land grant. As we detail the Valentine's claims they will intertwine with Pierre Dolet's lands. We also must briefly stray from the Adaes Indians for a short time as the land claim history of the Valentine's should be addressed thoroughly and this includes some claims within the Yatasi Indians lands around Bayou Pierre Lake.

Andre Valentine had been living in the Bayou Pierre region probably since the 1780 s. He purchased land from the Yatasi chief Cocais (Cocay), but the date of the purchase is unknown as we only have a partial document for the sale (Melrose Collection Folder 579). It is possible that Andre Valentine was the original owner of the tract of land claimed by Louis Procella in Rio Hondo claim \#239 (ASP 1859:136) in section 2 of T12N R12W. It is also possible that the Louis Procella archaeological site (16DS212) in DeSoto Parish is actually associated with Valentine's occupation and not Louis Procella. All plat maps of T12N-R12W show Procella as living on the western side of Mundy Bayou nearly $3 / 4$ miles from the area of 16DS212.

It is also apparent that the Procella family probably evacuated Nacogdoches, Texas in 1813 as a result of the failure of the Gutiérrez-MaGee Expedition. The entire town fled the Spanish forces that were heading toward Nacogdoches and many of these refugees settled in the Bayou Pierre settlement while most were settled around the Adaes region near Robeline, Louisiana and over to the Bayou Scie settlement (Pleasant and Pleasant, 1990). Louis Procella's Rio Hondo claim states he had been on this claim since 1814 along with his father and mother. It is obvious that by 1824 , the Procellas are back in Nacogdoches along with a large contingent of those who fled the town in 1813; this was due to Mexican independence in 1821. Regardless, the Procellas were late arrivals to Bayou Pierre or at least to this tract of land.

In the 1797 inventory of ranches in the Nacogdoches jurisdiction, Andre Valentine is listed as living at "Laguna de Arroyo de las Piedras" or Bayou Pierre Lake (Bexar 1797). This is possibly the location of the land he purchased from the Yatasi and is possibly part of the Yatasi village "Anadehes". This area is adjacent to the claim of Marcel Desoto who petitioned for land along Bayou Pierre Lake in 1783. Desoto's petition states that he claims "une Vacherie aux yatasses dans un endroit nomme anadehes vacant" (Melrose collection Folder 579). Basically he was claiming an abandoned Yatasi ranch in an area named "Anadehes". The location of Marcel Desoto's Rio Hondo claim \#238 is known from many plat maps of T12N R12W and T13N-R12W.

Valentine's claim could be not located on any plat maps and this is probably due to it being occupied and then possibly abandoned well before the United States gained possession of the Louisiana territory and survey plat maps began to be produced. The claim attributed to Andre Valentine was noted on maps within a publication by Louis Nardini. While the integrity of Nardini's work has been questioned due to a general lack of references for his data, the maps seem to be legitimate. A careful examination of the maps reveals that each known claim is situated in the correct area. We can only assume that perhaps Andre Valentine's claim is also 
plotted correctly, but from some unknown source map. The inventory of ranches in 1797 lists him as having a ranch on Bayou Pierre Lake, and that is where this map shows his claim to be located. If this is correct then we have to presume that Valentine's claim was also part of "Anadehes" along with Marcel Desoto's adjacent claim. The Louis Procella site (16DS212) must also be regarded as possibly being remains of that Yatasi vacherie.

Andre Valentine received a Spanish land grant in 1791 within the Adaes villages, however, this grant had a peculiar history. It was claimed by Joseph Valentine in his Rio Hondo claim \#87 (ASP 1859:105-106) in the 1820s but in a conveyance between Joseph Valentine and William Buford in 1819 the grant was mentioned as:

being the same as granted to Andrew Valentine by the Spanish Government and by the said Andrew Valentine transferred to the present vendor [NPC 1819].

This indicates that Andrew Valentine signed over the rights to the land to his son Joseph Valentine at some point between 1791 and 1819.

Joseph Valentine was born on December 3, 1791 but is recorded in his Rio Hondo claim as receiving the Spanish land grant in 1791 which is obviously impossible. The grant petition was submitted on August 5, 1791 approximately four months before Joseph Valentine was born. I believe it is fairly obvious that it was his father Andre Valentine that originally received the land grant and during the Rio Hondo claims Joseph submitted the claim as his. The name on the grant was conveniently torn on the English translation.

Regardless of who received the grant from the Spanish authorities the information within the claim is important. A handwritten translation of the grant is located in the Rio Hondo files at the Louisiana State Land Office and is basically the translation presented in Joseph Valentines Rio Hondo claim \#87 which states:

whereas [torn] has appeared by petition, bearing date the 5th of August, in the present year, one thousand seven hundred and ninety-one, praying, with due submission, that the tract of land called Adaes, because the tribe of Adaes occupy it, may be granted him, I do grant it to him for the object of his petition mentioned [ASP 1859:105-106]

The claim is stated to be located south of Bayou Pierre with Bayou Macdown as its northern boundary and Red River as its eastern boundary and the claim was a mile and a half square. This is essentially the same text as the conveyance to William Buford mentioned earlier indicating we are dealing with the same tract of land. The 1819 conveyance from Joseph Valentine to William Buford described the land as being:

on the Bayou Pierre branch of Red River in the settlement of Bayou Pierre to wit: one certain tract on the south settlement side of said river having Bayou McDown for its northern boundary: its eastern boundary being Red River one mile and a half square [NPC 1819]

Once the area for Bayou Macdownis defined, thie will narrow the possible locations for the Valentine grant and the location of the Adaes villages mentioned. This is possible by cross referencing Pierre Dolet's claim and Bayou Macdown.

A purchase of land by Joseph Valentine from François Serpentine in 1820 gives a good boundary description, and this time it is possible to connect the Dolet claim and Bayou Macdown or Macdonald (Macdon). 
The conveyance states the claim is "bounded on the west by lands belonging to Pierre Dolet. On the south by Bayou McDonald, the east by Bayou Pierre [NPC, 1820]." This narrows this tract of land down to a small area on the east side of Pierre Dolet's claim and also narrows the location for the bayou named McDonald (Macdon) as being within or adjacent to his grant.

Joseph Valentine sold a tract of land to an Andrew Valentine who was either his father or brother both of whom was named Andrew (Andre). The document suggests this is the actual home of Joseph Valentine and it is situated along Bayou Adaes. The document states:

A certain portion of land situated and being on the Bayou des Adayes in the parish aforesaid; containing twelve arpens front on said bayou with the depth of forty arpens be the same more or less with all the Buildings and improvements thereon being; bounded on the upper side by lands belonging to the heirs of Pierre Dolet and below by land of Vendor; it being the same plantation on which said Vendor now resides; and being in the Bayou Pierre settlement". [NPC n.d.]

As stated earlier the location of Pierre Dolet's claim is indisputable. Any claim that references Dolet's claim can be relegated to a small area. I has already been concluded that Dolet Bayou was referred to as the Bayou of the Adaes. Pierre Dolet as well as François Prudhomme and Andre Rambin are all stated to be living along the Bayou of Adaes. The difference is there are definitive locations of their claims due to plat maps and various other documents.

In the last of Joseph Valentine's conveyances the Adaes Indians and Pierre Dolet's claim are directly associated for the first time. In 1819 Pierre Roblot sold a tract of land to Joseph Valentine in which the document states:

being in the parish of Natchitoches in the Ancient Village of Adyies. Received by declaration of Pierre Dolet by deed bearing date of August A.D. 1809 bounded above by lands belonging to said Pierre Dolet and below also by the said Pierre Dolet. [NPC, 1819]

Though this conveyance states the land is in Natchitoches Parish it should be noted that Natchitoches parish at that time included the area of southern DeSoto parish. This once again associates the presence of Adaes villages with the area around Dolet Brake and Chamard Brake as well as along Dolet Bayou.

It can once again be inferred that Valentine's claim was located adjacent to or perhaps within Pierre Dolet's claim, as it was often the case that grants overlapped. It is also clear that Bayou Macdon, Bayou Macdown and McDonald are the same bayou, simply spelled differently in the various documents. What is not definitively known is whether Bayou of Adaes and Bayou Macdon are one and the same, or whether they are two different bayous in the same general area. At this point it can only be suggested that Dolet Bayou, or a smaller bayou such as Bois D'arc bayou, is Bayou Macdon. 


\section{Lac Macdon}

In 1805 Doctor John Sibley the Indian agent at Natchitoches, Louisiana described the locations of various tribes west of the Mississippi River and north of the Rio Grande. This was ultimately included by Thomas Jefferson in a report on the travels of the Lewis and Clark expedition. The description of the Adaize Indians is somewhat limited but it has caused endless speculation for two centuries. In his report Sibley states the Adaize:

Live about forty miles from Natchitoches, below the Yatassees, on a lake called Lac Macdon, which communicates with that division of Red River that passes by Bayou Pierre. they live at, or near, where their ancestors have lived from time immemorial. They being the nearest nation to the old Spanish fort or mission of Adaize, that place was named after them, being about twenty miles from them, to the south. [ASP 1832:722]

If the earlier evidence suggesting that Lac Macdon was Dolet Brake is correct, then we can verify Sibley's description of the location of the Adaize as being approximately twenty miles north of Los Adaes. Webb and Gregory (1986) had suggested a possible location for this village on Allen Plantation, and while there is definitely a historic component at the site which possibly represents an Adaes occupation, this component is clearly not the Lake Macdon site mentioned by Sibley.

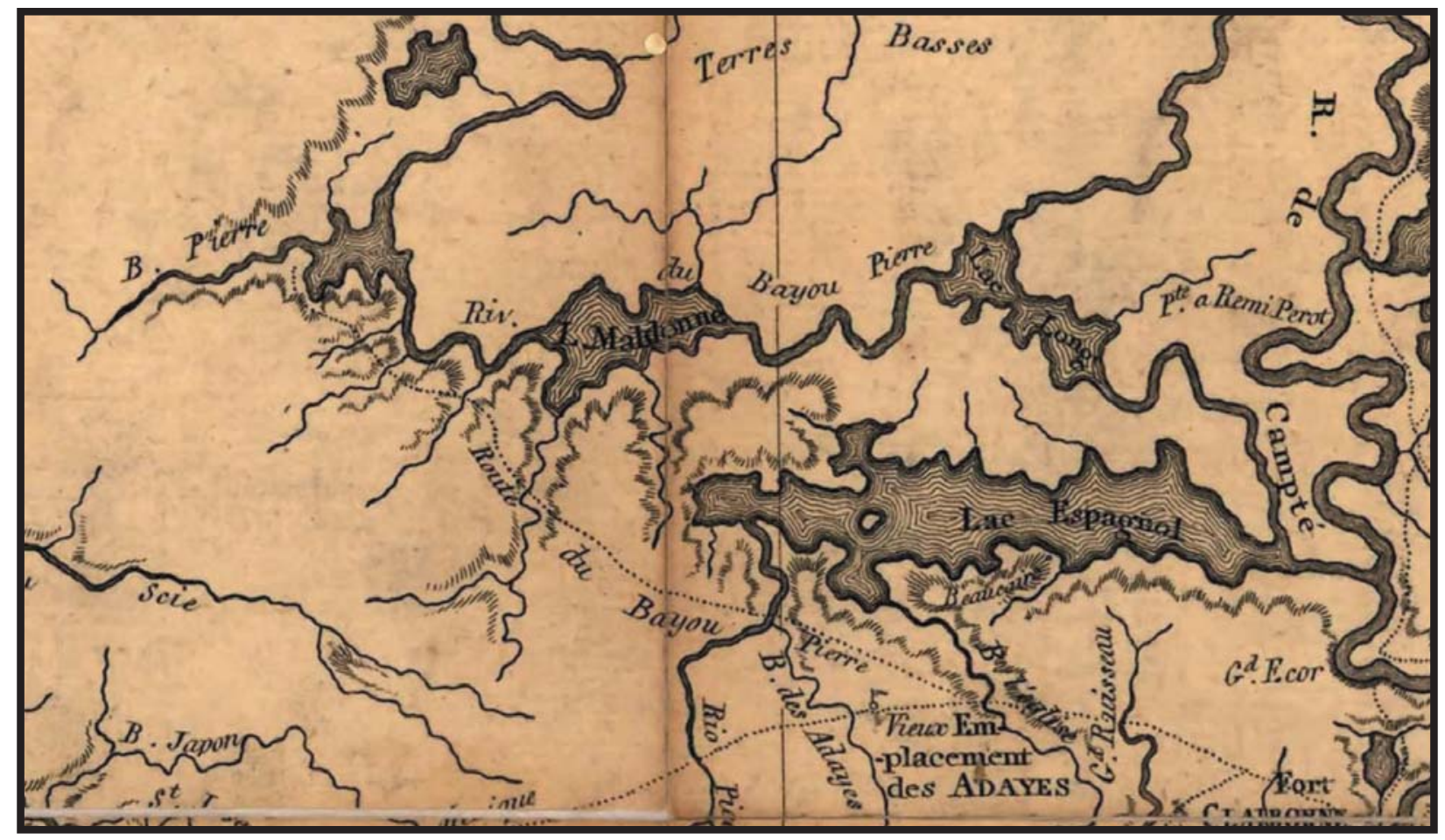

Figure 4 Excerpt of the Barthelemy Lafon 1806 map showing Lake Maldonne between Lac Espagnol (Spanish Lake) and Bayou Pierre. It is obvious that this is the same body of water known by various names such as Lake Macdon, Lake McDown and Lake McDonald. The lake is presumed to be Dolet Brake. 
The Allen (16NA4) site is eight miles south of Lac Macdon (Figure 4) and overlooks modern Topicote Bayou. This is the closest historic Indian site to Los Adaes discovered so far. Beginning in the 1780s the immediate region was claimed as a vacharie by Remy Totin Sr. and after his death by his son Remy Totin Jr. and later by Bernard Pantaleon dit Issura. In the 1790s Bernard Pantaleon dit Issura married the widow of Remy Totin Sr. and claimed four square leagues of land under Register \#A29 (ASP 1859:498) at Tapalcot and had a Spanish concession for the land dating to April 20,1798. The witness testimony by John Sibley states that the land was occupied in 1804 and for 20 years previous to the date of the concession by Pantaleon and the late Remy Totin Sr. (ASP 1859:498). The land along Topicote Bayou was claimed in the 1820s by Remy Totin Jr. in Rio Hondo claim \#227 (ASP 1859:134). The land was held until the mid 1830s when Remy and Charles Totin sold their combined lands which essentially consisted of all the holdings of the Totins in the immediate area. A history of the land conveyances is described under claims \#106 by the legal representatives of Bernard Pantaleon and \#172 by the widow and heirs of William Bullitt (US Serials 1842:51-53, 72).

It is obvious the Allen Plantation site was settled by the Totin family during the same general time the Lac Macdon site is settled by the Adaes Indians. The only logical manner for the historic Allen site to be contemporary to the Vacherie is for the Totins to have Native farm hands or allowed natives to encamp upon their property. It is also plausible that the site pre-dates the Vacherie; this is unknown in part due to a lack of real diagnostic remains.

\section{The Village of Adaes Confusion}

The name of this settlement has created confusion as to whether it refers to a village of Adaes Indians or to a village located in the geographic region of the former presidio and mission named after the Adaes Indians. The Village of Adaes (Pleasant and Pleasant 1990) was first inhabited around 1813 by refugees from East Texas, specifically the Nacogdoches region. There were inhabitants in the surrounding area before this, but the founding of the village occurred because of the influx of new people. These immigrants settled on Emmanuel Prudhomme's Spanish land grant in western Natchitoches Parish surrounding present day Robeline, Louisiana. John Cortes acting as a witness in Emmanuel Prudhomme's Rio Hondo claim \#110 states:

in the year 1813 he was on the land claimed, with the claimant, at the time of the emigration of a number of Spaniards from Texas and that while there a number of Spaniards demanded of the claimant permission to reside on the land claimed, which was granted on condition that, when they quit, their improvements and houses should belong to the claimant; and that under said permission said Spaniards settled, and have lived on, and cultivated said land ever since to the present time[ASP 1859:110].

The descriptions of the village within the succeeding Rio Hondo land claims reveal a definite Spanish cultural orientation to the village.

One particular immigrant from Nacogdoches Manuel Bustemento (Bustamente) on whose claim the village was actually situated was from Jalapa, Mexico (Bexar Archives 1805). Manuel Bustemento claimed "a tract of land lying within the late neutral territory, situated in the village of the Adais" [ASP 1859:121]. Manuel Bustemento's neighbor within the village was Trinidad Candido, who was also from Nacogdoches and along with several other residents of the village lists identical descriptions of their claims. 
Another well-known inhabitant of the village-also a refugee from Nacogdoches-was José Antonio Sepulveda. Many of Sepulveda's descendants live in Sabine Parish today. Rio Hondo claim \#188 was filed by Pavie and Noyrit with José Antonio Sepulveda as the assignee, which meant Sepulveda sold the land to Pavie and Noyrit at some point previous to the claim filing. The date of the filing was in 1824 and it is probable that he had already returned to Nacogdoches by that time as had other refugees such as Louis Procella. Another document from 1836 gives more detail about the claim around the village. In a request for a certificate for the tract of land Pavie and Noyrit state:

said claim is situated about 16 miles from the town of Natchitoches at a Spanish town called the Adyas [LSLO 1836:35-36]

There is another statement indicating that the village is inhabited by people considered Spanish. What is interesting about José Antonio Sepulveda is that in a grant document for his ranch in Nacogdoches County Texas he is listed as being from Mexico. The grant states:

José Antonio Sepulveda originario de la villa de San Carlos Capital de la colonia el Nuevo Santander [TGLO 1825]

Nuevo Santander is now the Mexican state of Tamaulipas in the Northeastern part of the country just south of the Brownsville, Texas. The small town of San Carlos was once its capital. Genealogical documents state he was also a Spanish soldier around the Rio Grande area before he migrated to Nacogdoches.

Many of the so called Adaeseños in western Louisiana are descendants of either Manuel Bustemento or José Antonio Sepulveda, including the author. It is evident, however, that the original nationality through Bustemento and Sepulveda was Spanish. Sepulveda's father-in-law José Ramon Chavana was originally from Lampazas, Nuevo León before migrating to Nacogdoches (NCRP1809).

The probable house sites of Trinidad Candido and José Antonio Sepulveda were found and archaeologically recorded in 1989 (Pleasant and Pleasant 1990). The sites on the surface and in test units yielded only European artifacts, with the exception of a few prehistoric points and ceramics dating several hundred years earlier. Manuel Gonzales filed a claim just to the west of the village in what is today Sabine Parish. This claim is immediately adjacent to Manuel Bustemento's claim and is described as

a tract of land lying within the late neutral territory, situated on the road leading from Natchitoches to Ormegas, about one mile west of a Spanish village [ASP 1959:107]

Another Rio Hondo land claim to the east of the village belonging to María Conception De Leon described a similar setting. It states "a tract of land lying within the late neutral territory, and situated in a Spanish village" (ASP 1859:103).

In addition to land claim descriptions, the village was subsequently mentioned by several people who passed through in the early 1800's including soldiers from Ft. Jesup and various travelers. Timothy Flint on his journeys to the Spanish frontier passed through the village in1824 on his way from Natchitoches.

We went out of the great road, Camino Real, as it used to be called, to visit the Spanish village of Adayes. It is a curious collection of great, upright log houses, plastered with mud, and having an appearance very different from a French village of the same character. [Flint 1826:370-371] 
What is apparent is the absence of any mention of the Adaes Indians or any Native Americans within the Rio Hondo claims for this region. As noted throughout this paper all references to the Adaes Indians locate them in Desoto Parish or northern Natchitoches Parish. With the above statements from claimants and witnesses there should be no mistaking the Village of Adaes for a Native American village. It is indisputably a Spanish settlement.

These people are referred to as Spanish in the above citations and in the many Rio Hondo claims. During the span of the Village of Adaes and afterwards it is known as "Old Spanish Town" and the new settlement a few miles north was known as "New Spanish Town". We need to understand the commonly used term "Adaes" or "Adayes" as being a geographical reference to the area around Los Adaes and not a reference to the presence of the Adaes Indians. No different than Natchitoches being a town and not a tribal location.

\section{Discussion}

The historic location of the Adaes Indians can finally shed some light on the affiliation of the historic archaeological sites around Dolet and Chamard Brakes and the surrounding region. These historic sites are near where the land claims revealed the Adaes to be living. This can provide a stepping stone into further studies of the historic Indians of the region now that we know where they were.

There will remain lingering questions regardless of the evidence put forth in this article. These include 1) Is there any trace of an historic Adaes Indian site near Los Adaes? 2) Is the site of the presidio or mission masking a pre-Spanish Indian village site? At this point in time, there is no evidence of a village outside of the presidio and mission area, and it is also not known if a village was present within the mission or presidio. If one was there it is surely mixed and became part of the greater historic archaeological site.

The artifact remains of the historic Indians in the northwest Louisiana region literally show no change during the eighteenth century, despite claims by others such as Schambach and Miller (1984) and Perttula (1992) of great cultural transition during this period. Basically the ceramics recovered from early eighteenth century sites reveal no real change in ceramic types and only minimal changes in varieties when compared to later sites. All definitive historic Native American sites have a similar ceramic content throughout the region of northwest Louisiana with the exception of sites associated with later immigrant tribes. This is best viewed from the evidence from Los Adaes where there is no traceable change in ceramic types during the 50 year occupation at the site. There is variation in ceramic types at Los Adaes but this is due primarily to the fact there was so much cultural interplay at the site. There are a vast number of tribal groups represented in the cultural remains at Los Adaes. Regardless of the variation within the remains none can be relegated to a pre-Spanish occupation at this time.

We know from the documentary evidence presented earlier that the Adaes Indians were centered on Dolet Bayou and the surrounding area, quite possibly from first contact, until they are no longer mentioned in the documents. We also know that currently there is no evidence of historic Native American sites around the presidio of Los Adaes and the surrounding region. In all the research of the area near Los Adaes since the 1960s there has been no historic sites found that can be described as an Adaes Indian village.

The Adaes are mentioned within the land claim documents but they are always far to the north of the Los Adaes region. Conveyance records which mention the Adaes Indians are also always for tracts of land to the north as well. Historical accounts of travelers in the years after Los Adaes was abandoned never mention 
any Native Americans within the region of Los Adaes. Until archaeological sites are found or until archival documents are discovered which indicate historic Native American sites in the region, there is no proof that the Adaes were ever residents of the region around Los Adaes.

Without getting too deeply embroiled in the history of the Los Adaes presidio, it does appear that perhaps the mission and presidio were situated in a more political setting than a cultural one. Did the Spanish place the mission and presidio amongst the Adaes Indians or did they place the mission and presidio in a politically strategic locale and coax the Adaes Indians to the area? That is a topic I will leave to others to determine. My opinion on this subject has been presented within this paper.

Dolet Bayou and the surrounding area in southern Desoto Parish and northern Natchitoches Parish have an ample concentration of historic sites that can be attributed to eighteenth and early nineteenth century Indians. Some sites can be dated early within the historic period based on the European ceramics recovered. The Wilkinson Site (16NA3) has evidence of an early historic occupation as there is Puebla Polychrome II Majolica in the Williamson Museum collections at Northwestern State University. Puebla Polychrome II dates before 1725 (Fox and Ulrich, 2008:72). The presence of this ceramic type indicates that the occupants of the site were there during the same general time that Los Adaes was actually first settled.

There are issues with labeling sites as Native American within the Bayou Pierre region. Several sites that were long thought to be Indian sites are probably European sites. The most prominent was Pierre Dolet's Spanish land grant which was thought to be remains of a Yatasi village. The vast amount of documents available for this claim reveals this not to be the case. The archaeological site known as 16DS274 is indisputably the house and Vacherie of Pierre Dolet. The documents mention that the claim is actually centered upon the house of Pierre Dolet and 16DS274 is situated in the same area as his house. The cultural remains agree with the time frame of occupation by Pierre Dolet.

Another site farther to the south known as Rocks Bayou (16NA1) was reported by James Ford (1936) and has always been considered a historic Indian site. The site contained an array of historic materials both European and native. Research documents revealed that this too is probably a European site, more specifically the Spanish land grant acquired by François Morvan in 1799. He was living here possibly as early as the 1770s well before he received the grant from the Spanish authorities. The fact he was a known Indian trader and had several native women with him at times, and was reportedly married to one of the native women only makes the presence of Native American artifacts logical. These two sites reveal what will be an obstacle concerning archaeologically locating any Adaes Indian sites in the field. This is how to actually separate a Native American site from a European site if all contemporary peoples were potentially using the same goods etc. It may be that the only place they can be separated is within the documents available.

The last issue that comes to light when discussing the Adaes and also the Yatasi "ancestral grounds". is the following: "Where are the late proto-historic sites associated with either tribal group?" We know where each group was historically located within the Bayou Pierre area but there are no known proto-historic sites in the entire region. Why are there proto-historic sites in the vicinity of Shreveport and Bossier City, Louisiana but no historic inhabitants in the region? If the groups encountered along the Red River by Bienville were associated with the Yatasi or the Adaes then it almost seems as if they simply crossed the Red River valley to where they are historically known to have lived. There is definitely a lack of legitimate historic sites near Shreveport and Bossier City, those peoples encountered in that region moved somewhere and it is plausible they moved to the Bayou Pierre region. 
This same issue also concerns the Natchitoches Indians farther south. There is a nice sample of historic sites along Cane River and also in the uplands around Natchitoches, Louisiana that can be attributed to the Natchitoches Indians. However there is a paucity of evidence for proto-historic occupations in the area.

We know where the Yatasi and Adaes were located during the eighteenth century-the only question remains is where are the archaeological remains dating between Belcher times and these Historic tribes? We have a starting point for the local historic period around 1721 when the Spanish arrive en masse-now we just have to work our way backwards to find where each tribal group actually came from. This is a potentially contentious topic that will be addressed at a later time.

\section{References Cited}

American State Papers (ASP)

1832 Class II: Indian Affairs. Vol. 4. Gales and Seaton, Washington.

1834 Class VIII: Public Lands. Vol. 3. Duff Green, Washington.

1859 Class VIII: Public Lands. Vol. 4. Gales and Seaton, Washington.

Annals of Congress

1852 Ninth Cong., $2^{\text {nd }}$ sess., $1209-1216$.

Avery, George

1995 Annual Report for the Los Adaes Station Archaeology Program. Submitted to the Louisiana Division of Archaeology, National Park Service, and Louisiana Office of State Parks

1997 Annual Report for the Los Adaes Station Archaeology Program. Submitted to the Louisiana Division of Archaeology, National Park Service, and Louisiana Office of State Parks

1998 Annual Report for the Los Adaes Station Archaeology Program. Submitted to the Louisiana Division of Archaeology, National Park Service, and Louisiana Office of State Parks.

Bexar Archives

1797 Census drawn by José María Guadiana. Bexar Archives. Microfilm, Roll 027:77. Cammie G. Henry Research Center, Watson Library. Northwestern State University.

1805 Census of houses east of the Sabine River by José María Guadiana. Bexar Archives. Microfilm. Cammie G. Henry Research Center, Watson Library. Northwestern State University.

1809 María Ramben, Declaration of Allegiance to Spanish Flag. Bexar Archives. Microfilm. Cammie G. Henry Research Center, Watson Library. Northwestern State University.

1810 Census made by José María Guadiana. Bexar Archives. Microfilm. Cammie G. Henry Research Center, Watson Library. Northwestern State University

Bolton, Herbert Eugene

1914 Athanaise DeMézières and the Louisiana-Texas Frontier, 1768-1780. 2 vols. Arthur H. Clark Company, Cleveland.

Buckley, Eleanor Claire

1911 The Aguayo expedition into Texas and Louisiana, 1719-1722. The Quarterly of the Texas State Historical Association 15:1-65. 


\section{References Cited (cont.)}

Colonial Archives

1789 Adai Nation to Athanase Poisot. Document \# 2176. Colonial Archives, Clerk of Courts Office. Natchitoches Parish Courthouse.

Coles, Harry L.

1979 History of the Administration of Federal land policies and land tenure in Louisiana, 1803-1860. Arno Press, New York

Ekberg, Carl J.

1998 French Roots in the Illinois Country: The Mississippi Frontier in Colonial Times. University of Illinois Press, Urbana.

Flint, Timothy

1826 Recollections Of The Last Ten Years. Cummings, Hilliard, And Company, Boston, Massachusetts.

Ford, James A.

1936 An Analysis of Indian Village Site Collections from Louisiana and Mississippi. Anthropological Study 2. Louisiana Geological Survey, Baton Rouge.

Fox, Anne A. and Kristi M. Ulrich

2008 A Guide to Ceramics from Spanish Colonial Sites in Texas. Center for Archaeological Research, The University of Texas at San Antonio.

Glover, William

1935 A History of the Caddo Indians. The Louisiana Historical Quarterly 18: 872-946.

Gregory, Hiram F.

1998 Personal Communication.

Haggard, J. Villasana

1945 The Neutral Ground Agreement Between Louisiana and Texas, 1806-1821. The Louisiana Historical Quarterly 28: 1001-1128.

Hodge, Frederick editor

1907 Handbook of American Indians North Of Mexico. Part 1. Smithsonian Institution, Bureau Of American Ethnology, Bulletin 30. Washington, Government Printing Office.

LaVere, David

1998 The Caddo Chiefdoms: Caddo Economics and Politics, 700-1835. University of Nebraska Press, Lincoln.

Lafon, Barthelemy

1806 Carte générale du territoire d'Orléans comprenant aussi la Floride Occidentale et une portion du territoire du Mississipi / dresée d'après les observations les plus récentes par Bmi. Lafon, ingénieur géographe à la N[ouve]lle. Orléans. http://www.loc.gov/item/2003623380, Accessed August 9, 2012. 


\section{References Cited (cont.)}

Louisiana State Land Office (LSLO)

1836 Record Book Spanish Claims. Document No. 510.00367.

Melrose Collection

Cammie G. Henry Research Center, Eugene P. Watson Library. Northwestern State University, Natchitoches, Louisiana.

Nacogdoches Census Report Project (NCRP)

1809 http://www.sfasu.edu/heritagecenter/100.asp Manuel Bustemente, Nacogdoches Census, 1809, page 11, website accessed in May 2012.

Natchitoches Parish Courthouse Conveyances (NPC)

n.d. Joseph Valentine to Andre Valentine.

1819 Pierre Roblot to Joseph Valentine.

1819 Joseph Valentine to William Buford.

1820 François Serpentine to Joseph Valentine.

National Park Service (NPS)

2011 El Camino Real de los Tejas National Historic Trail. Comprehensive Management Plan/Environmental Assessment. United States Department of Interior. Washington D.C.

Perttula, Timothy

1992 The Caddo Nation: Archaeological and Enthnohistorical Perspectives. University of Texas Press, Austin.

Pleasant, Randall and Darryl Pleasant

1990 The Adaes Village: Archaeological Research on an Nineteenth Century Spanish-American Site. Paper Presented at the 1990 Caddo Conference, Natchitoches, Louisiana.

Schambach, Frank and J.E. Miller

1984 A Description and Analysis of the Ceramics. In Cedar Grove: An Interdisciplinary Investigation of a Late Caddo Farmstead in the Red River Valley, edited by Neal Trubowitz, pp. 109-170. Arkansas Archaeological Survey, Research Series 23, Fayetteville.

Sibley, Dr. John

1922 A Report from Natchitoches in 1807. New York Museum of the American Indian, Heye Foundation, New York, New York.; reprinted in 1996 by Dogwood Press, Woodville, Texas.

Smith, F. Todd

1995 The Caddo Indians: Tribes at the Convergences of Empires, 1542-1854. Texas A\&M University Press, College Station.

Smith, Ralph A.

1958 Account of the Journey of Benard de la Harpe: Discovery Made by him of Several Nations Situated in the West. The Southwestern Historical Quarterly 62:246-259. 


\section{References Cited (cont.)}

Swanton, John

1946 Indians of the Southeastern United States. Bureau of American Ethnology. Government printing Office, Washington. Bulletin 137.

Texas Beyond History (TBH)

http://www.texasbeyondhistory.net/adaes/worlds.html.Accessed May 20, 2012.

Texas General land Office (TGLO) http://scandocs.glo.texas.gov/webfiles/landgrants/pdfs/1/0/3/4/1034246.pdf Accessed August 17, 2012

United States Congressional Serial Set (US Serial)

1842 H.R. Doc. No. 33, 27 ${ }^{\text {th }}$ Cong., $2^{\text {nd }}$ Session.

United States Statutes at Large (Statutes)

1805 Act of March 2, 1805, ch. 26, 2 Stat. 324-329

1807 Act of March 3, 1807, ch. 36, 2 Stat. 440-442

1812 Act of March 10, 1812, ch. 38, 2 Stat. 692-693

1813 Act of February 27, 1813, ch. 38, 2 Stat. 807-808

1814 Act of April 14, 1814, ch. 52, 3 Stat. 121-123

1819 Act of March 3, 1819, ch. 86, 3 Stat. 517

1820 Act of May 11, 1820, ch. 87, 3 Stat. 573-575

1823 Act of March 3, 1823, ch. 30, 3 Stat. 756-757

1824 Act of May 26, 1824, ch. 182, 4 Stat. 65

1835 Act of February 6, 1835, ch. 17, 4 Stat. 749-750

1854 Act of August 3, 1854, ch. 204, 10 Stat. 347

Webb, Clarence H. and Hiram F. Gregory

1986 The Caddo Indians of Louisiana. Anthropological Study 2. Louisiana Department of Culture, Tourism and Recreation, Baton Rouge.

Wedel, Mildred Mott

1978 LaHarpe's 1719 Post on Red River and Nearby Caddo Settlements. The Texas Memorial Museum, The University of Texas at Austin, Bulletin 30. 